\title{
Thinking into the Bog: Art Practice and Connection from inside a Language under Pressure
}

\author{
Ian Joyce and Mathew Staunton
}

\section{(2) OpenEdition \\ 1 Journals}

\section{Electronic version}

URL: https://journals.openedition.org/etudesirlandaises/8811

DOI: 10.4000/etudesirlandaises.8811

ISSN: 2259-8863

\section{Publisher}

Presses universitaires de Caen

\section{Printed version}

Date of publication: 24 September 2020

Number of pages: 67-87

ISSN: 0183-973X

\section{Electronic reference}

lan Joyce and Mathew Staunton, "Thinking into the Bog: Art Practice and Connection from inside a Language under Pressure", Études irlandaises [Online], 45-1 | 2020, Online since 24 September 2020, connection on 17 November 2022. URL: http://journals.openedition.org/etudesirlandaises/8811 ; DOl: https://doi.org/10.4000/etudesirlandaises.8811

\section{(c) (i) (2) (2)}

Creative Commons - Attribution-NonCommercial-ShareAlike 4.0 International - CC BY-NC-SA 4.0 https://creativecommons.org/licenses/by-nc-sa/4.0/ 


\title{
Thinking into the Bog: Art Practice and Connection from inside a Language under Pressure
}

\begin{abstract}
In this article Ian Joyce and Mathew Staunton explore the interconnected notions of anxiety and contemporary art practice in Ireland by "thinking into the bog" and looking with fresh eyes from inside the Duibheagán, the inky depths at the heart of the natural world and the day-to-day experience of a language under pressure. Via Munch's scream of nature and its Irish equivalent in the devastating and uncanny creative force unleashed by Uaigneas, they look for artistic sense in the metaphorical, linguistic and physical spaces in and around the bog landscape of County Donegal.
\end{abstract}

Keywords: art, art practice, space, anxiety, uncanny, Irish language, bog, nature, landscape.

Résumé: Dans cet article Ian Joyce et Mathew Staunton confrontent la notion d'anxiété à la pratique artistique contemporaine en Irlande à travers une "pensée de la tourbière" qui reconsidère le Duibheagán, les profondeurs noires émanant du monde naturel, et l'expérience quotidienne d'un langage/d'une langue étouffée. Les auteurs décèlent dans la force créative libérée par le / la Uaigneas un équivalent irlandais au Cri de Munch et déploient un espace métaphorique, linguistique et physique dans et autour des tourbières du Donegal.

Mots clés: art, pratique artistique, espace, anxiété, uncanny, langue irlandaise, tourbière, nature, paysage.

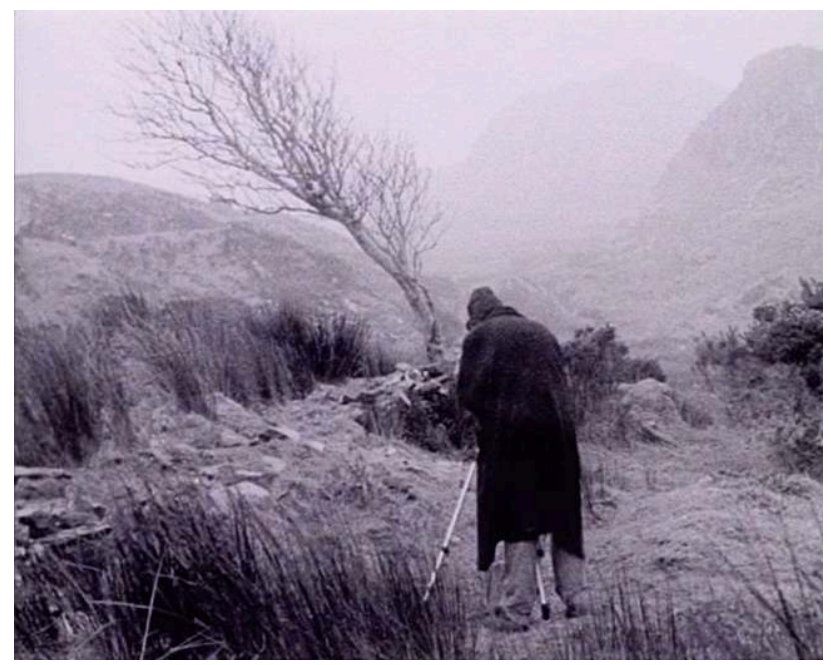

Fig. 1 - Still from short film by Ian Joyce, Bealach na'Bhealtaine, 1998-2005. 


\section{A is for Art and Anxiety}

My fear of life is necessary to me, as is my illness. Without anxiety and illness, I am a ship without a rudder. My art is grounded in reflections over being different from others. My sufferings are part of myself and my art. They are indistinguishable from me, and their destruction would destroy my art $^{1}$.

(Far too) often quoted in (overwhelmingly superficial) discussions of Edvard Munch's ${ }^{2}$ mental health and sometimes that of other "tormented" artists like Van Gogh, Pollock, Plath and [insert artist of your choice here], the above passage from the Norwegian artist's journal does much more than suggest an intimate connection between anxiety and art. It gives us an insight into the lived experience of makers across every spectrum, time, domain and territory. Anxiety is not the cause or the result of art, what happens when an artist fails or succeeds, or simply an affliction often suffered by artists: it is infinitely more. There can be no art without anxiety. It is the engine that drives all research and every act of creation. Art and anxiety are two sides of a same coin.

Reading anxiety as a negative (as is done to Munch, despite his best efforts) tends to close down the possibilities of art, short-circuiting its social function in particular. Art and madness become enmeshed: artists are mad, art is mad. In the black hole of negation, all detail goes missing. The work is boxed off, imprisoned between the extremities of sensationalist biographical text.

In this article we set about disentangling the notion of anxiety from the bear trap of negation being dragged along behind the physical and artistic (exquisite) corpse of contemporary art. We go walkabout and find ourselves in wetlands up to our oxters. "Thinking into the bog", neither a methodology nor a work in progress, we physically sift the ground, mingling our guts in mud and muck and black bog water. We refigure anxiety from deep inside the morass of the Duibheagán, the depths, the deep experience of life, stripping back the layers to anchor ourselves in the bedrock of literary and folk lore from which the Gaeltacht makes its stand and its claim on land and kinship.

Under pressure and fighting for its life, the Irish language releases adrenaline, a sense of community, a common sense and sensibility and a plethora of strategies that allow us to look at art (and anxiety) in a different setting and to circumvent concepts that interfere with artistic work by introducing a sense of disabling alienation into the work space. Along with Duibheagán, we will focus on the interrelated concepts of Uaigneas, and Dinnseanachas, and set them up as resources for engaging with makers and making in Ireland today.

1. Edvard Munch, Munch Papers, T2748, Munch Museum, Oslo.

2. Edvard Munch (1863-1944) was a Norwegian painter now known throughout the world almost exclusively for his iconic painting The Scream. Under the mentorship of nihilist Hans Jæger, he developed the practice of "soul painting" to compellingly depict his emotional and psychological states as they evolved. 


\section{$\mathrm{M}$ is for Modernity and looking the wrong way down a telescope}

We (Joyce and Staunton) engage with anxiety as the reality and form our experience takes. From this perspective, there is something unnaturally smooth about the surface of art history, art criticism, art schools and art-speak. Clearly, there is something unnaturally smooth about modernity (and its myth of never-ending progress) in general. We (over-optimistically?) expect art to expose the tears, cracks, bleeds, dog ears, creases, stains, and arbitrary signs of decay, preservation and change which have been papered over by versions of modernity but, instead, we witness the systematic deflection of young artists from the messy, sticky, intimate, multi-faceted realities of their own lives, systematically dissociated by their learning and obligatory commercial activities from day-to-day experience. The ubiquitous and desperately tidy binary setting of tradition against modernity disguises a missing third term almost always made to go astray in the wish fulfilment of a self-congratulatory intelligentsia.

Becoming an artist is a one way ticket to Desperation with a capital D. Fed by the self-same dissociation of modernity from day-to-day experience, the realities of personal experiences transmitted through family ties, personal relationships and life encounters are edited away ${ }^{3}$. Encouraged to create and regurgitate personal biographies, capsizing in a sea of anxiety is the inevitable consequence of the impossibility of reconciling multiple identities while producing a marketable, commercializable unit of art. I must interpret myself, interpret my own work, promote my own work, sell my own work, sell myself ${ }^{4}$.

Let's slow down, shift our viewpoint, and see what comes into view. Looking out through the jaws of the bear trap, looking out from the interior of living experience, the opposition tradition/modernity does not add up. This should come as no surprise: these are not separate positions at all but merely interchangeable perspectives whose boundaries are purposely blurred to aid and abet the impact of current affairs as news from the other side of the planet speeds up and drowns out self-identification, forcing the pace of war and the dissemination of technologies of surveillance. One of the lesser known of the arbitrary points used to separate modernity from what came before is the invention of the telegraph in the $1840 \mathrm{~s}^{5}$ and its rapid deployment throughout the world. From that moment on, accounts from distant battlefields, international catastrophes and the minutiae of the lives of celebrities in every field began to take priority over what was happening locally. We knew more (and became more anxious about) situations over which we had no influence while those things on which we could actually lay our hands diminished from our view. Today, making and makers alike are increasingly caught up in this

3. As this issue obviously also involves people other than artists, it is worthwhile approaching it via the later work of German sociologist Ulrich Beck and his Cosmopolitan Vision (Ciaran Cronin (trans.), Cambridge, Polity Press, 2006) in particular. Coincidentally, this almost coincides with that other crucial (retrospective) cut-off point in the context of Irish modernity: the Great Famine.

4. First person statements by Ian Joyce are set in italics in the text.

5. On 24 May 1844, Samuel Morse sent Alfred Vail the first telegraphed message: "What hath God wrought!". 


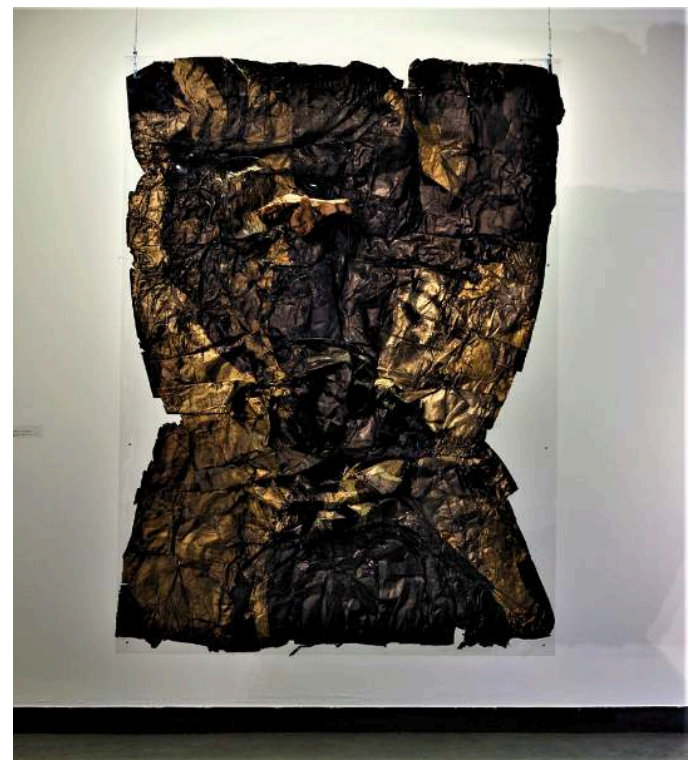

Fig. 2 - Ian Joyce, For Konstantnidis, thread, ink, recycled texts, bog oak, Perspex, 2015, Kostakis Collection, State Museum of Contemporary Art, Thessaloniki.

Photo credit: Ian Joyce.

process of rapid historicization, the contextualization and recontextualization of forms de-familiarized from the contexts in which they were originally conceived.

When we are busy making things, whether it be building a dry stone wall, baking soda bread, making a turf stack or improving the $\mathrm{pH}$ of a field with lime, we work to a different rhythm and inhabit a different temporality. Tradition and modernity are connected in the movements and gestures of our bodies as they work. T. S. Eliot calls this the "historical sense":

Tradition $[\ldots]$ cannot be inherited, and if you want it you must obtain it by great labour. It involves, in the first place, the historical sense [...]. This historical sense, which is a sense of the timeless as well as of the temporal and of the timeless and of the temporal together, is what makes [an artist] traditional. And it is at the same time what makes [an artist] most acutely conscious of [his / her] place in time, of [his/ her] contemporaneity ${ }^{6}$.

It is this historical sense that we are made to forget in the chaos of modern communication.

In Ireland, what is called "modernity" peeps through a reverse lens, a telescope pointed away from the raw data of experience and a foil to a traumatized past, be it the detonation of nuclear blasts on Nagasaki and Hiroshima, the industrialization of murder by the Nazis and their allies, or the depopulated wasteland projected by a generation of Irish nationalists. The old, like the real, is not abandoned so much as hospitalized and put on a life support system behind protective Perspex. We can approach it only if we wear masks and gloves and refrain from raising our voices.

6. T. S. Eliot, “Tradition and the Individual Talent” [1919], Perspecta, vol. 19, 1982, p. 37. 


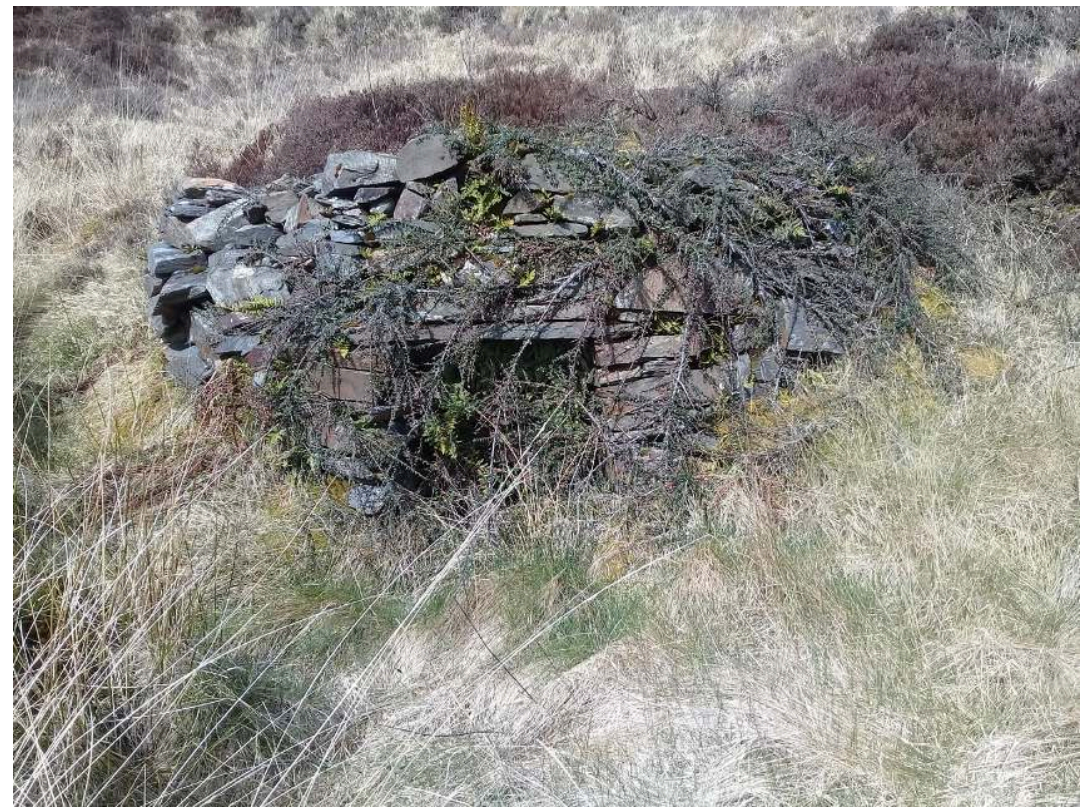

Fig. 3 - Ian Joyce, Abandoned lime kiln, Mín a' Leá, 2020.

Depending on who is in government, it may require termination or resuscitation. Down on its luck, and in need of alms, it is set aside, segregated, deselected, and quietly and unapologetically licensed to vanish of its own accord.

Without terms of opposition, difference or contradiction there are no grounds for "legitimate" dispute or protest. The smooth surface of contemporary art offers no handholds for dissenters. Even the insights which academic education sometimes encourages by default are damped down and left out to dry. Projecting modernity as a cultural phenomenon, while it fosters the appropriation of many hybridized art activities, art-speak is used as a species of sociology in reverse, symptomatic of an equivocation encouraged by the cultural powers that be, to pacify us in the trivial pursuits of a manic conformism. The "creative industries" and the petrification of creativity are the inevitable results of over-commodification and the entrapment of identity and identity politics in the mish-mash of warring ideologies endlessly recycled. Put more simply (if turning the clock back to the 1970s and 1980s and applying a Lukácsean / Althusserian / Marxist critique can be considered simple), a close reading of the discourse of art in Ireland offers only a superficial glimpse of what art is but a profound insight into the dominant ideology that has parked itself on top ${ }^{7}$.

7. We are thinking of "What is Orthodox Marxism?" in particular (in Georg Lukács, History and Class Consciousness. Studies in Marxist Dialectics, Rodney Livingstone (trans.), Cambridge, MIT Press, 1971, p. 1-26), originally published, like Freud's "Das Unheimlich" and Eliot's "Tradition and the Individual Talent”, in 1919. 
So where do we look for the missing third term? As we have suggested above, it is on (and especially in) the historical language of the people of Ireland that we instinctively focus our attention, going as far as to climb inside it and look through its eyes, through the eyes of Suibhne ${ }^{8}$, at the circumambulating contemporary landscape.

\section{$\mathrm{U}$ is for Uaigneas and uncanny}

Returning to Edvard Munch with this question on our lips, we find in The Scream an expression of a very particular form of anxiety. Not a depiction of his usual fear of life and/ or death, urban angst, rage or alcohol-fuelled depression, this was an attempt to represent an unexpected and overwhelming interaction with the natural world. The English (French, Spanish, Italian, etc.) title of the work is misleading. Despite a century of popular misperception, the person in the image is not screaming. (S)he is holding her/his ears. Munch's original German title, Der Schrei der Natur, tells us why. Nature is screaming:

I was walking along the road with two friends - the sun was setting - suddenly the sky turned blood red - I paused, feeling exhausted, and leaned on the fence - there was blood and tongues of fire above the blue-black fjord and the city - my friends walked on, and I stood there trembling with anxiety - and I sensed an infinite scream passing through nature ${ }^{9}$.

For most commentators, The Scream speaks the language of anxiety as disturbance, absence, madness or social isolation. Munch literally framed the 1895 pastel version of the work in such a way (including most of the above passage) that this reading would be difficult to sustain but it has taken hold, nonetheless, and, limpet-like, will not be budged. We can do better. Working against the grain of a century of received (mis)interpretation which articulates the exact opposite, we embrace the comforting conviction that Der Schrei der Natur tells the story of a moment of utter and inescapable connection.

We choose to engage with the (deliciously) ambiguous notion of connection glossed as isolation and absence via the Irish-language word Uaigneas. Generally translated as a version of loneliness or solitude ${ }^{10}$, it approaches the English word "uncanny" (and the content of Freud's 1919 essay Das Unheimliche ${ }^{11}$ ) in certain

8. Buile Suibhne (The Madness of Sweeney) is the story of Suibhne mac Colmáin, king of the Dál nAraidi, who was driven insane by the curse of Saint Rónán Finn. This caused him to leave the Battle of Mag Rath and spend the rest of his days wandering in the wilderness.

9. Translation by Reinhold Heller of an entry in Munch's 1892 diary, quoted in Reinhold Heller, Edvard Munch: The Scream, s.l., A. Lane, 1973, p. 107.

10. Niall Ó Dónaill's Foclóir Gaeilge-Béarla unimaginatively offers "loneliness" or "solitude" as the primary definitions with "eerie" appearing in an example sentence supporting a tertiary meaning.

11. First published as Das Unheimliche in volume 5 of the Leipzig-based pyschoanalytical journal Imago in 1919 and translated as The Uncanny in volume XVII of The Standard Edition of the Complete Psychological Works of Sigmund Freud, James Strachey (ed.), London, Hogarth Press, 1955, p. 217-256. 

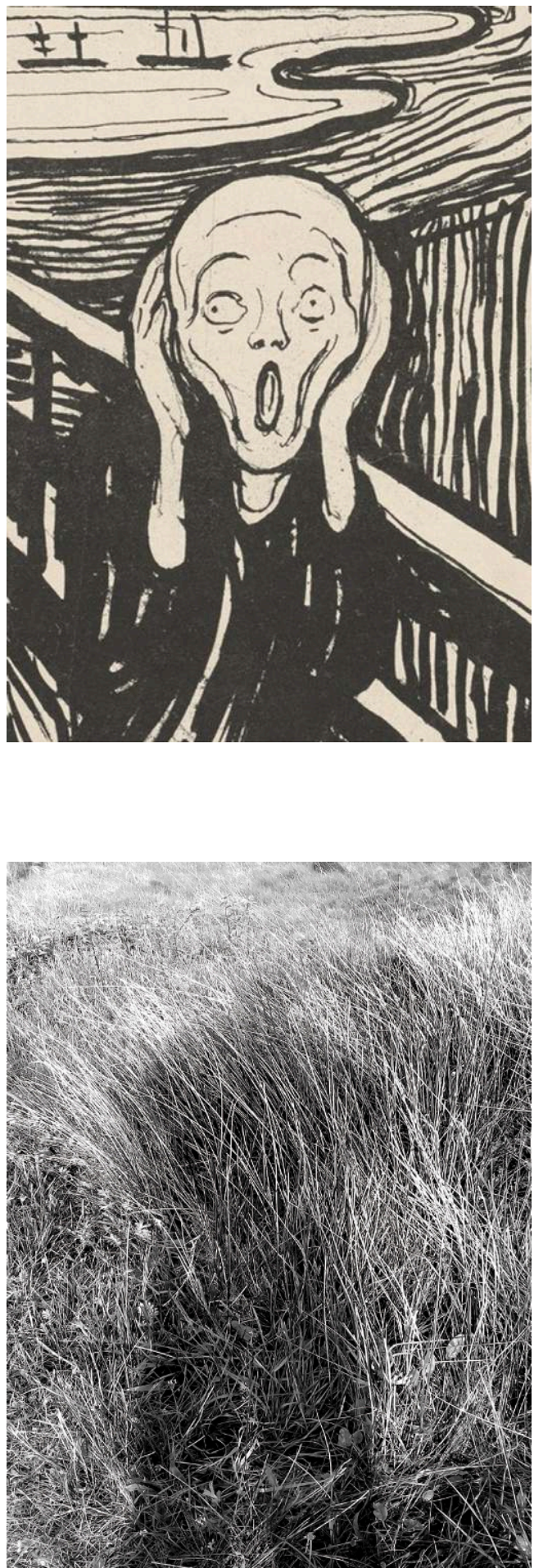

Fig. 4 - Detail of The Scream, 1895, lithograph by Edvard Munch.

Courtesy of the Munch Museum, Oslo.

Fig. 5 - Ian Joyce, Scáil, 2019. 
contexts (encounters with ghosts, dips into darkness and the eruption of the past into the present), but forks away at the last minute, ultimately acquiring a profoundly different resonance, particularly in County Donegal where the osmosis of sense between landscape and language means that, if anything, Uaigneas binds rather than untethers a person. The psyche is saturated and sinks down into the home place, the ancestral setting. Uaigneas is not alienation from the mores of civilization, the insanity of the sick, or the unseemly gaga of the half-mad affronting social norms. It is the moment we plunge our hands up to the elbows in the flowing, pumping life force of the world around us. Emily Dickinson was an old hand at plunging and breathlessly bears witness to one of her experiences in this astonishing (untitled) poem:

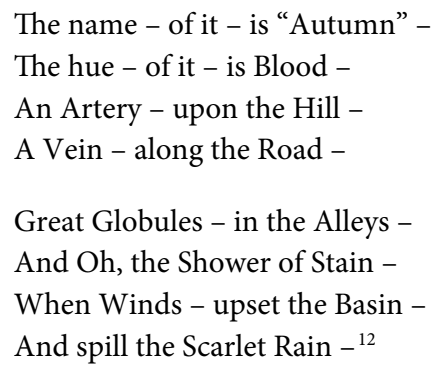

Far from the violent spectacle of fields irrigated by blood (still unapologetically evoked in the Marseillaise ${ }^{13}$, for example) or (as some might argue) a visceral memory of Civil War battles fought in the neighbourhood of Dickinson's house ${ }^{14}$, this poem expresses the transitional terror provoked by sudden access to topos of place, the physical power and presence of the stuff in which flesh and blood cohabit: the blood and bones, butter, bog holes, water springs, flag irises, and roots of trees which conspire with the elements and all that inhibits communication, slowing down the human frame into an aeon of clotted solidification. It is the scream of nature rather than the scream, the cacophony of non-human voices in which the half-living and the half-dead awaken in the tundra of their imaginable natural forms.

It is also very much the blue-black fjord and blood-red sky in Munch's Scream and the devastating connection he felt one day on the winding road up to the park on Ekeberg Hill, not with the nearby city lunatic asylum but with the apocalyptic annihilation of the volcanic island of Krakatoa on the other side of the planet and the ash, volcanic dust and gases that would make sunsets spectacular for an entire decade all over the world ${ }^{15}$. These same sunsets illuminated the works of French

12. Emily Dickinson, The Complete Poems of Emily Dickinson, Thomas H. Johnson (ed.), Boston, Little, Brown and Co., 1961, p. 656.

13. Qu'un sang impur abreuve nos sillons...

14. See David Cody, "Blood in the Basin: The Civil War in Emily Dickinson's 'The name of it is Autumn"', The Emily Dickinson Journal, vol. 12, no. 1, 2003, p. 25-52.

15. On 27 August 1883, four explosions almost entirely destroyed the island. These were heard $3,110 \mathrm{~km}$ away in Perth, Western Australia. The pressure wave from the third and most violent explosion was recorded on barographs around the world. 
Impressionists who expressed a radical dissociation from the Academy not as angst or alienation but as an individualistic and intimate immersion into the network of ephemeral sensations surrounding them, be it in the play of light on a cathedral facade or the visual distortion caused by traffic on a London bridge. They plunged their eyes and ears, followed closely by their paintbrushes, into the ambience. But even this unmistakably radical new direction was not really a break with the old. As Eliot has elegantly (and convincingly) pointed out, the past is altered as much by the present as the present is directed by the past:

The existing monuments form an ideal order among themselves, which is modified by the introduction of the new (the really new) work of art among them. The existing order is complete before the new work arrives; for order to persist after the supervention of novelty, the whole existing order must be, if ever so slightly, altered ${ }^{16}$.

We identify a similar plunge (to Dickinson's blood-bath) in Connemara writer Máirtín Ó Cadhain's novel Cré na Cille. Ó Cadhain eschews circumglobal connections to focus on the intensely local, exploring in intimate detail the verticalities of the Irish landscape, connecting what we perceive on the surface with the subterranean forces and the irrationality of the depths ${ }^{17}$. Consider the following extract:

I am the Trump of the Graveyard. Let my voice be heard! It must be heard...

Here in the graveyard the spectre of Insensibility is violating coffins, grubbing up corpses and kneading the decayed flesh in his cold earth-oven. [...]

Above ground the tufts of bog-cotton are on every hummock of the marsh. The meadowsweet is a divine pharmacist in every meadow. The fledgling seagulls are fluttering gently in the wrack of the shore. The playful voice of the child in a pen can be heard in the proud growth of the ivy on the house gable, in the boastful branching of the thorn-bushes in the hedgerow and in the protective roof of the trees in the grove ${ }^{18}$.

Ó Cadhain stands, pen in hand, at the doorway through which the scream of nature erupts into our consciousness and extremities of mycelium strands emerge to connect us to bits of our ancestors, treasure troves and stories. The journey to and from those depths, the pedagogy which crystalizes in and around us during the trip and the wisdom with which we return is the stuff that art is made from. The Irish word for depths (and, as is the case with Uaigneas, much more besides) is Duibheagán. It connects blackness $(d u b h)$ with the depths of an ocean or an abyss (aigéan), expressing the dirty geography of Ó Cadhain's underground drama, the unfathomable depths of the Vernian ocean (Duibheagán na farraige), the blackest darkness of night (Duibheagán na hoíche) and the reciprocal gaze of Nietzsche's abyss (Agus má fhéachann tú fada isteach sa duibheagán, féachfaidh

16. T. S. Eliot, “Tradition and the Individual Talent”, p. 37.

17. For an insight into this type of space see Gaston Bachelard, The Poetics of Space, Maria Jolas (trans.), New York, Penguin, 2014, p. 39.

18. Máirtín Ó Cadhain, Graveyard Clay - Cré na Cille, Liam Mac Con Iomaire, Tim Robinson (trans.), New Haven, Yale University Press, 2016, p. 94. 
an duibheagán ar ais ionat freisin ${ }^{19}$ ). The rashest of rash acts is the jump of a sheep into the ocean: léim caorach i nduibheagán.

\section{C is for Cló}

Cló \& The Living Archive, the twin artistic endeavours of Ian Joyce, are situated geographically and conceptually on a site associated with Uaigneas and the Duibheagán County Donegal. The original stone house at the heart of Joyce's base in Mín a' Leá (near Gortahork) was abandoned by its family when an unlucky man (making whiskey, by all accounts) drowned in the lake on which it sits and, according to local lore, d'eirigh siad uaigneach. A quick translation of this phrase by an outsider (even a native speaker from outside Donegal) might misrepresent the situation and imagine the family being overwhelmed by a sense of solitude or loss and driven to establish a new home a short distance up the road. This misrepresentation is similar to the unfortunate redescription that morphs Munch's Der Schrei der Natur into The Scream. It comes close but the essence of the situation is overlooked and crucial details are lost. Local people, more sensitive to the living experience of their neighbours and the archetypes released by the Irish language, and immersed in a shared pool of stories would understand that something more profound had taken place: the death of the unfortunate amateur distiller had opened a doorway to another realm (death, the fairy kingdom, the past), and the family were being haunted by their own heightened senses and an overwhelming connection (just as devastating and intense as that of Munch) to their environment. Living on the threshold of that doorway was simply too much.

But for the artist living there now, the intensity of life on the limen is a source of artistic empowerment rather than an overpowering and devastating source of fear. For him, Uaigneas is bonded to the community, the unfragmented, flinty, stalwart community and its culture standing outside the mainstream as a collective solidarity rather than a radical act of survival and defiance. It is inextricably tied to the specific place through place lore, Dinnseanchas and auratic, expressive, mnemonic forms. Joyce describes it in the following way:

Cló was the idea of creating an artists' workshop using the possibilities of artisan or apprenticeship schemes available through the local economic authority (Uddaras na Gaeltachta). Providing a continuum of skills using traditional techniques of fine art printmaking with new media, forming the equipment and skill to address the local artistic needs of making craft and fine art a source of income and learning. Initially located, for a 10-year period in factory units on a former industrial estate in Gaoth Dobhair, the project, along with my own home, was located where it is now, on a 14-acre farm just at the foot of Mount Errigal,

19. Translation by the authors of "And when you stare for a long time into an abyss, the abyss stares back into you" (Friedrich Nietzsche, Beyond Good and Evil, Rolf-Peter Horstmann, Judith Norman (eds.), Judith Norman (trans.), Cambridge, Cambridge University Press, 2002, p. 69). 


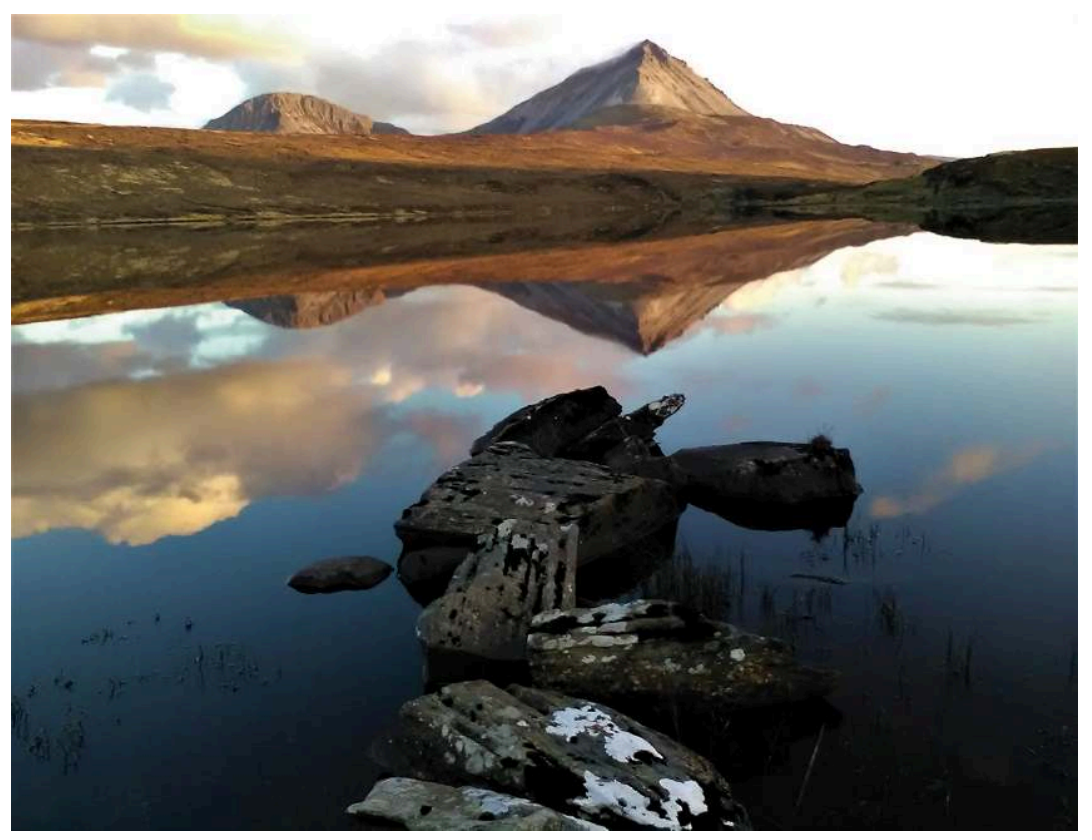

Fig. 6 - Ian Joyce, Loch an Gainimh, 2019.

in the townland of Min a' Lea (the place of the flagstones) in the parish of Clochaneally, one of three distinctive Gaelic-speaking areas, where I settled in 1998, moving with my young family from Belfast.

The location, itself, the landscape, culture and environs remain for me the positive pole of a bipolar magnet for a journey in imagination driven by the need to reconnect to a mother tongue whose demise is announced at regular intervals through the organs of state broadcasting authorities attuned to the politics of public opinion and the motivational ideology of small businesses and trans-national commerce.

If there is an identity question it is also a question of identity as an inner psychological need to defend, as a norm, a universal human impulse to be "at home", "i mo theaglach", "i mbun mo dhúcais".

With my Art, such an endless journey as this trapped in an infinite regress of self-repression and denial, stemming from early childhood, an experience of "being and becoming" in a language not my own, a language culture disassociated from the continuities and traditions of a country whose traumatic social collapse is now a central focus of political, social and cultural studies in Ireland known as "the Great famine".

Over a period of 20 years working with Cló \& The Living Archive, I invited artists from the Irish, Scottish, transatlantic and European Celtic language areas, and also "analogous cultural situations" worldwide from Armenia, Iran, Georgia, Sardinia, Crete and the Irish / Gaelic speaking diaspora in Canada, America to spend time at Teach an tSléibhe.

The stone floored the room of the once abandoned old house, unlived in for 200 years, until it became, as it now is, a home for the nomadic spirit of migrating words, songs and ideas, the artistic project which is part and parcel of my own work. 
A version also, perhaps, of Eliot's historical sense, Uaigneas captures in its sound and music the architecture of time, the community of the living and dead under the roof of the heavens. As in Buile Suibhne (The Madness of Sweeney), it is the unadorned life in the wilderness, in which experience is scaled back to the rhythms, changes and transient, generalized movements of nature: a little twirling wind, the Séideán Sí - a sliding glow flame over the bog at night, a tune trapped in the crevice of a house, a sheep dog licking his shadow on the corner of a giant stone, a shadow on dry grass late on a summer evening. As in sean nós song this constitutes a calculus of feeling as accurate as any clock, and as telling as the most complex measure of pressure possible to a barometer.

\section{D is for Duibheagán}

We might, if we are not careful, brush up against the frontier of the Gothic here. For many people, the Irish bog is a mythical space, inescapably present (the large blank space on the map) and necessary to our sense of reality of the empirical world, simultaneously a resource and a frustrating barrier, but always difficult to pin down semantically. It lies beyond the pragmatic level of action and perceptual experience ${ }^{20}$, extending out from the fuzzy edges that fringe direct experience of the world and known only indirectly through symbolic means ${ }^{21}$.

American writer of weird and horror fiction H. P. Lovecraft ${ }^{22}$ takes the Gothic path to the Irish bog and positions it at the dark heart of his strange 1926 tale "The Moon-Bog" ${ }^{23}$. In this, his only story set in Ireland, he projects his usual racist fantasies onto superstitious Catholic peasants (rather than Asian- or AfricanAmericans) and sees in the otherworldly sights and sounds of the bog the perfect backdrop for a tale of terror:

When I heard the fears which had driven the people from Kilderry I laughed as loudly as my friend had laughed, for these fears were of the vaguest, wildest, and most absurd character. They had to do with some preposterous legend of the bog, and of a grim guardian spirit that dwelt in the strange olden ruin on the far islet I had seen in the sunset. There were tales of dancing lights in the dark of the moon, and of chill winds when the night was warm; of wraiths in white hovering over the waters, and of an imagined city of stone deep down below the swampy surface. But foremost among the weird fancies, and alone in its absolute unanimity, was that of the curse awaiting him who should dare to touch or drain the vast reddish morass. There were secrets, said the peasants, which must not be uncovered ${ }^{24}$.

20. See Alfred Irving Hallowell, Culture and Experience, Philadelphia, University of Pennsylvania Press, 1955, p. 187.

21. See Yi-Fu Tuan, Space and Place: The Perspective of Experience, Minneapolis, University of Minnesota Press, 1977, p. 88.

22. Known (and mostly loved) especially for his creation of what is now called the "Cthulhu Mythos" but increasingly denounced for his racism.

23. H. P. Lovecraft, "The Moon-Bog", Weird Tales, 1926, p. 805-810.

24. Ibid., p. 807. 
Here the bog is merely a stand-in for the swamps of Louisiana that figure elsewhere in Lovecraft's corpus and the saturated portion of the ocean floor thrown to the surface by volcanic activity in Dagon, "exposing regions which for innumerable millions of years had lain hidden under unfathomable watery depths" 25 or even a version of the backlot reconstruction of Arthur Conan Doyle's Grimpen Mire on the set of the 1939, 1959 and 1983 cinematic productions of The Hound of the Baskervilles. It is an aesthetic that can be reproduced in a studio to provide atmosphere but it has no depth. There are no bog bodies or gossiping locals underneath its surface. No stories lurking in lime kilns or sheep droppings. No Duibheagán.

For the artist in Mín a' Leá it is an altogether different story.

My work, for all its abstract and playful formlessness, is entrenched in memorialization or "making memory". As far as possible, I avoid the narrative pressure, as well as the cultural politics of the "dead generations" - who died of unnatural causes - and concentrate on the idea, prevalent in Irish literature, of the bog as a repository of the "naturally dead" but in whose memory the seasons and natural world are the co-ordinates of a continuing and unstoppable life, the continuum of communal social interchange. As I understand it, these are the chimera, humourless, brittle, unpredictable, changeable and cantankerous presences that preoccupy us and make for the psychopathology of everyday life.

My instinctive interest in the surface of the support; its fragility; porousness of the paper, canvas, card or cloth is to do with making visible what is conventionally edited out and hidden in the traditional fine art media. Tares, bleeds, dog ears, creases, stains, are arbitrary signs of natural environment, decay, preservation and change which are coaxed into "process". Traditional conservation is in reverse gear, I preserve for posterity signs of the limits of meaning, and enjoy and participate in the natural signs of cyclical decrease and increase, metamorphosis, change and gradual growth.

Joyce also describes a profound connection to the landscape circumjacent to his home and studio, including regularly plunging his arms into it:

The material of the bog itself, the materials I find there, the plants, microcosm of miniatures, naturally occurring set designs, myriad objects and detritus are the object of daily gathering and the chores of sorting, organizing, cleaning, and preparation. Sometimes, out on my own, I have difficulty carrying back the booty, I will share with no one; even my closest friends and artistic co-workers, who come and work with me are banned from removing a single precious object of these esoteric meanderings. This summer, using turf mold and sphagnum moss, we [Joyce and Staunton] "re-invented" paper, an ineffably consistent, strong and flexible printing surface along with an "environmentally friendly" paint and etching ink. My need to fill my house and studio with a strange combination of drying plants, rotting metal, and all sorts of found objects was fuelled by my deepening conviction that cultivation and Art are one and the same. Together, objects that had previously lived out their afterlives in the bog became a shared resource of experimentation and inspiration.

25. H. P. Lovecraft, "Dagon", in The H. P. Lovecraft Omnibus 2: Dagon and Other Macabre Tales, London, Grafton Books, 1985, p. 12. 


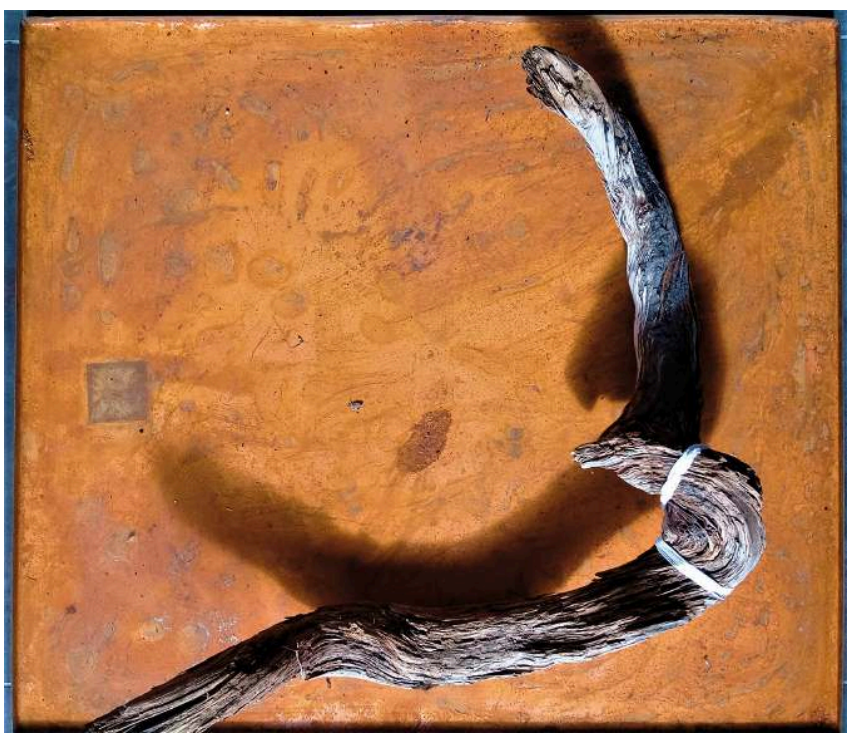

Fig. 7 - Ian Joyce, Dheisú, bog oak, string and steel, 2019.

Photo credit: Ian Joyce.

What does it feel like to venture into the Duibheagán and return with arms full of artistic booty? Poe's "The Pit and the Pendulum" ${ }^{26}$ explores the darker side of this experience. The pit was a frequent protagonist in the American literature of his day, and authors like Ralph Waldo Emerson ${ }^{27}$ and Dickinson were known to pace thoughtfully around its circumference, bridge across it with their imaginations, peer down into it, sometimes (especially in the case of Emily Dickinson) diving in and rooting around in the darkness. Uaigneas is the experience of lingering by the mouth of the pit and absorbing the extravaganza of sensual stimuli that engulf us on the homely side of the threshold. Sensitive people (the family of the amateur distiller, for example) can be overwhelmed. The artist stands (as a proxy for the rest of us) on the threshold itself and translates for those further away. When we embrace the Duibheagán we cross the limen and, with an intense psychological and emotional effort, explore the contours of the landscape beyond.

Here are some impressionistic snapshots taken in and around the Duibheagán before, during and after the work of creation:

26. First published in 1842, "The Pit and the Pendulum" details the torments endured by a prisoner of the Spanish Inquisition as his imagination is driven to its breaking point by fiendishly designed attacks on his senses.

27. Emerson wrote in a note in 1886: "There may be two or three or four steps, according to the genius of each, but for every seeing soul there are two absorbing facts, - I and the Abyss". Unlike Dickinson, he did not peer too deeply. See Patrick J. Keane, Emerson, Romanticism, and Intuitive Reason: The Transatlantic "Light of All Our Day", Columbia, University of Missouri Press, 2005, p. 405. 
1.

Accidental works occur naturally. Newsprint, stains, bleeds, accidental marks, all go into making the images appear to grow of their own accord. Series is the best and most productive way I can find to deal with newspaper images saturated with current affairs and which pile up neatly in bundles.

Seeing is believing. Working in the dark, whether in the photographer dark room, where I etch plates using water from Loch an Gainimh or the "tobar" (well). Presences present themselves for inspection willy nilly. Drawing in dark places is also drawing in the dark, with the lights switched off and with my eyes closed. The whispering grafite or blunt pencil sets up a sonic sensitivity to rhythm and pattern.

Musicians and my own children are often the subject of a species of automatic drawing which follows rhythmic and tonal attributes. Texts obliterated and washed out in natural solvents are the stuff best suited for subject matter.

My practice is fuelled and informed by anxiety.

2.

I stand momentarily. I drift off into thought. Something catches my eye. Keep warm, I say to myself, keep working, moving.

I work sporadically.

I look out the window.

No-one about. I am standing stock still in a boiler suit. I walk up and down the studio. The aluminium surface shimmers and alternates a luminescent sheen and a dull opaque grey. I am adjacent to a large window. I approach the plate, attached to the partition wall, a dull shadow appears at upper middle of the plate. The plate is opaque. The light moves across the abraded surface. I can see my own reflection distorted in the slightly dented surface. I approach the plate. A shadow comes towards the surface to meet me. I reach with my burin to draw. I make an incision. I touch the plate and feel the plate. I close my eyes. It feels like skin. I wait. I work slowly. Every sound in the cavernous studio is amplified. The tool I am using disappears and reappears in another part of the space. The shadow is still there. It is breathing. A stain is now spreading across the surface of the plate.

What am I doing here? Why am I penetrating the plates surface? What am I drawing? The shadow is appearing and disappearing. I score the surface. The point of the etching needle penetrates the metal. I go through the surface into the material. The surface softens and yields. A change in the air pressure. It begins to rain.

3.

Peculiar qualities ofform slipping into shapelessness, proto-metamorphic powers of pattern solving and guess work, making, thought itself, the grip on things goes helter skelter. Day itself slips away. The Homo Sapiens of the Roman calendar goes Homo Hibernicus into the deep drains of a powerfully managed water table of fluid animation through the stimulation of darkness, and the transposition of energy onto the sense of sound, touch, imagination, repetition, patterns, suggestion, auto suggestion.

Common lore and common sense rule $O K$, inner energy anarchic, primitive religion, ground prejudices, meld into a groundswell of trans-pantheistic know how, there is no God, but Gods, no person, but persons, no voice but voices: a sea of sliding deconstructiveness and marvellous mind-bending slippage, of disembodied voices, missing suggestions, words 
on their own, beings without parents, floods out and dissolve the diaphanous membrane of the "ego self" setting the scene for a single all-embracing receptor.

Rules of navigation, of ritual self-protection, come into play and mediate the liquefaction of the daytime familiar.

A kind of astral travelling, where the foot, hand and nose have equal measure of motion, commotion, locomotion, humming, singing, gentle breathing, sniffing are the engine that purrs the creature on.

When in the Duibheagán the character and personality plays tricks with the familiar gadgetry of people, places and objects alike. You may speak to jacks in loving tones while instructing a child obliquely in the wisdom of stones.

The darkness stimulates the inner eye, and body feels its way through amplification of sound, and the comprehensible expansion of the nature through anthropomorphic seeing and the faces of familiars light the way across the bogland, the traces of gaseous light, the still and troubled waters of the myriad lakes, and reflective surfaces and distant dimming windswept lights. An embracing darkness, all hell breaks loose.

Into the Duibheagán you go, without notions of return, space and time slide together and embrace. Light of day, makes invisible what the mind needs to see to fill in the gaps.

Faith healing, familiar faces, the senses mangled, test of the strength of a person, social outcasts, cast out the social, the rule book of the good citizen and queenly niceties, power of curses, shamanistic transportation, meteorites, glitter of water, natural music.

However, out of Duibheagán na hóiche (the darkness of night) and Poll duibheagáin (the bog hole) comes Duibheagáin smaointe, the profundity of thought.

The Duibheagán is a transition, provided you pass through, to recreation, rebirth, and is a local bardo, the transition through psychic disturbance to a fractile clear-headedness, a Palaeolithic shaping of experience into the ineluctable modality of the visible (after Stephen Dedalus). Not everyone survives. Some souls who do are known to have been incarcerated in the madhouse. Take Seosamh Mac Gríanna, a 20-year sojourn in St. Conall's in Letterkenny. "Bhí sé ró-chliste don saoil" (He was too intelligent for the road of life).

4.

I am on my way to my mother's house in Baltoney.

The sky is a greyish parchment. A filigree of clouds stretches above.

I came out to make photographs.

I have left my camera behind.

I pass below the bray.

The children in Cashel na gCorr school are out playing in the yard.

I am at the whalebone house. I stop to gaze at the trees. The leaves are whispering.

I don't remember my father talking to trees.

I dreamt about him this morning.

I was asking him not to cut a tree down that grew in front of an old house.

I see him whispering something into my mother's ear.

Please don't cut the tree down, I say.

In another part of the dream a photographer was out taking pictures.

He takes a picture of each one of us. 


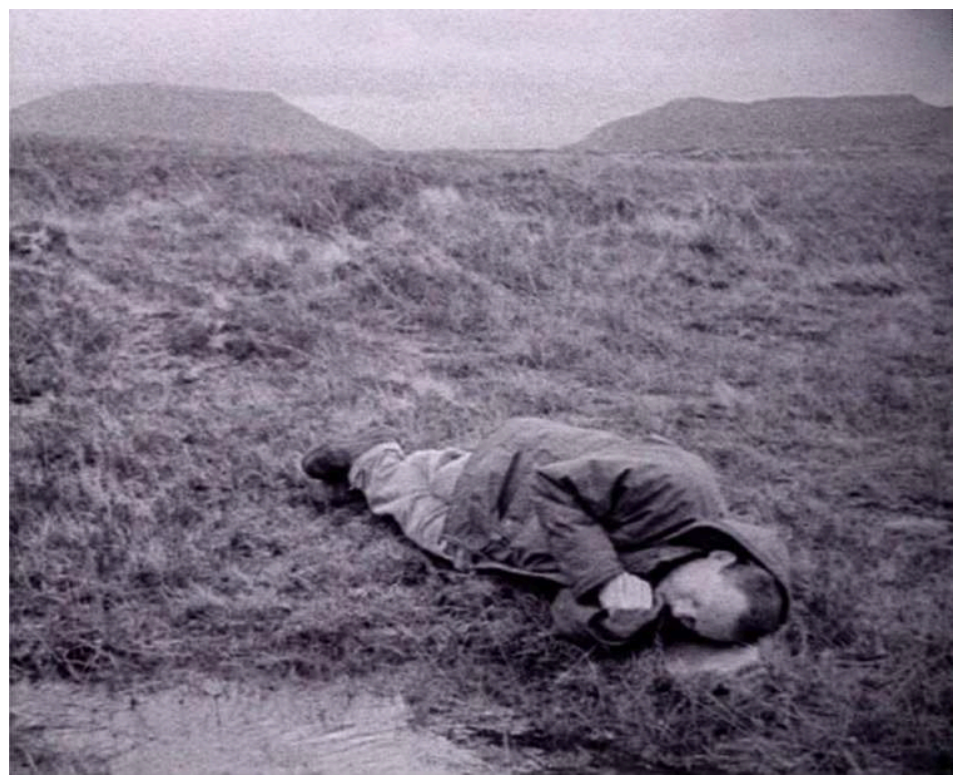

Fig. 8 - Still from short film by Ian Joyce, Bealach na'Bhealtaine, 1998-2005.

I am walking. The wind is in my face.

The reeds are waving over and back.

The road winds ahead.

I turn a curve of the bog road.

I come across a carcass of a car.

It is rusted down to the chassis.

A steering wheel stands to one side.

The field on the far side of Loch an Gainimh is scarred.

The bog lands are open wounds.

As I look back towards Teach an tSléibhe the poles are like match sticks.

A low drone sounds off the electricity cables.

I can hear morse code.

The little incline ahead, drum na gCíoch is bald and bare.

The Hawthorn trees at Caiseal na gCorr station are exhausted. I can see Tory Island. The lighthouse.

Flashes of light appear above the horizon.

I stop to rest. I sit for a while on white rock. I dangle my limbs. There is heather at my feet. I close my eyes and listen.

I grow drowsy.

I have a feeling that something strange is happening around me.

I open my eyes.

Somebody has spilt milk on the road side. 


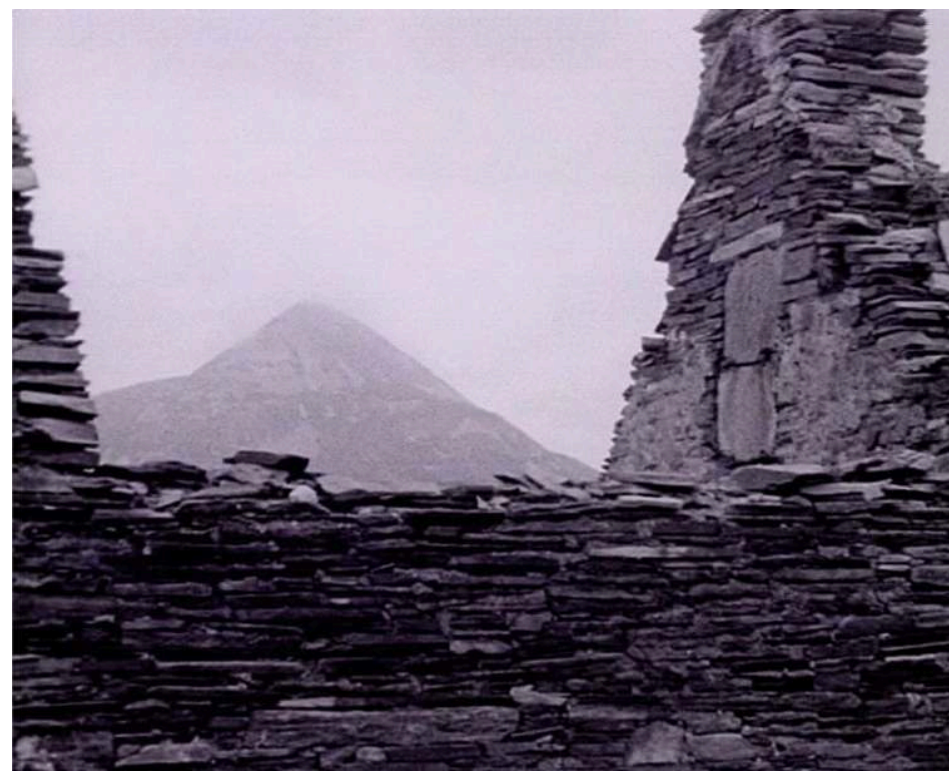

Fig. 9 - Still from short film by Ian Joyce, Bealach na'Bhealtaine, 1998-2005.

I look up the hill in the direction I am walking.

A silver chain.

The sun catches the pools of water.

I see spots of light. Sparks.

I notice two ravens high above Loch an Gainimh.

Pitch black.

I notice their shadows wheeling across the bog.

I remember my dream.

My father is lying in bed with the blankets pulled over him.

I am lying beside him.

The Duibheagán is part of the response to centuries of negative readings of the bog as a means of "othering" or alienating the people ("bog trotters") who lived there and designating them as inferior ("bog standard"). Those who want to recover the power to name and make sense of their environment have no choice but to do it from inside a linguistic and cultural position under pressure. The Duibheagán is this other space from which they work and Ian Joyce's art practice involves leading people around it, adding depth to otherwise depthless backdrops and postcard images as he goes.

What differentiates the Duibheagán from alienation is that in alienation we are trapped outside. The Duibheagán is a journey that can be detailed and documented, one that we can come back from (like Dickinson) with a story (like Poe's tortured narrators and Verne's Professor Pierre Aronnax) and a better understanding of ourselves. How do we adapt this journey to art practice? We name our anxiety 
and our movements through the landscape using Dinnseanachas (narrative place lore) and map-making. Initially, this process is metaphorical but, ultimately, it is translated into works and performances, exploring the human body, how we position it both in the landscape and relative to other people.

The bog is an open space, land that is not owned individually. It is the solid form of the collective unconscious. If you want fuel you have to go out and dig it. There are certain times of the year when you can dig it and foot it and lay it out to dry. If you want to seal your house against the elements you have to get lime, build a lime kiln, put the lime in, light a fire and stoke it over two days. This is not something from the past, from the historical, anthropological or archaeological imaginary, but something people can and still do today.

There are a plethora of practical things we can learn just by walking around the bog, looking at the basic conditions of a room in a ruined house (stone, a fire, a chimney to let the smoke out, an opening to bring in light), how to fertilize the land so that things grow in it, how to make the lime to insulate a building. As Karin Sanders has eloquently pointed out, the bog can also be seen as "nature's own darkroom with powers similar to those of photography" ${ }^{28}$. Over a period of two thousand years, "the mnemonic properties in these bog-laboratories of northern Europe have produced nature's own equivalent of photo-sculpture" ${ }^{29}$. The bog can teach us how to look, give us a dose of Eliot's "historical sense", transform a primitive life cycle into a technological basis for cultural life and art.

We enter in a state of distress and engage with a linguistic culture and landscape under pressure. What we learn helps us to come out. The bog is where the Duibheagán happens. The reason why we can get back out of it is that the ideas are waiting for us in the culture, locked into the language. By engaging with the landscape we get down to the bedrock of the language and that language is forced under pressure to give up its knowledge. If we live inside the language with our hands and skills we can do art with it.

\section{Conclusion}

Neither a manifesto nor a "bog standard" conference centre, Cló is a destination, a journey's end. Cló is an idea, a "Living Archive" of the place in which it sits: Mín a' Leá or Mín a' Lea $(g c) h a$, the place ( $m i n$ ) of the flagstones. It is also a collection of found objects, collected texts and reusable images, stored or deposited objects recycled in open-ended artworks that publicize artistry as the pursuits of everyday life; if being useless in the present can be brought to life in an afterlife of the "real", the fine art of the slow lane of ealaíon agus an cultúr nua aimsire (modern art and culture), not exactly a doorway into the future but at least a very early retirement

28. Karin Sanders, Bodies in the Bog and the Archaeological Imagination, Chicago, The University of Chicago Press, 2012, p. 25.

29. Ibid. 


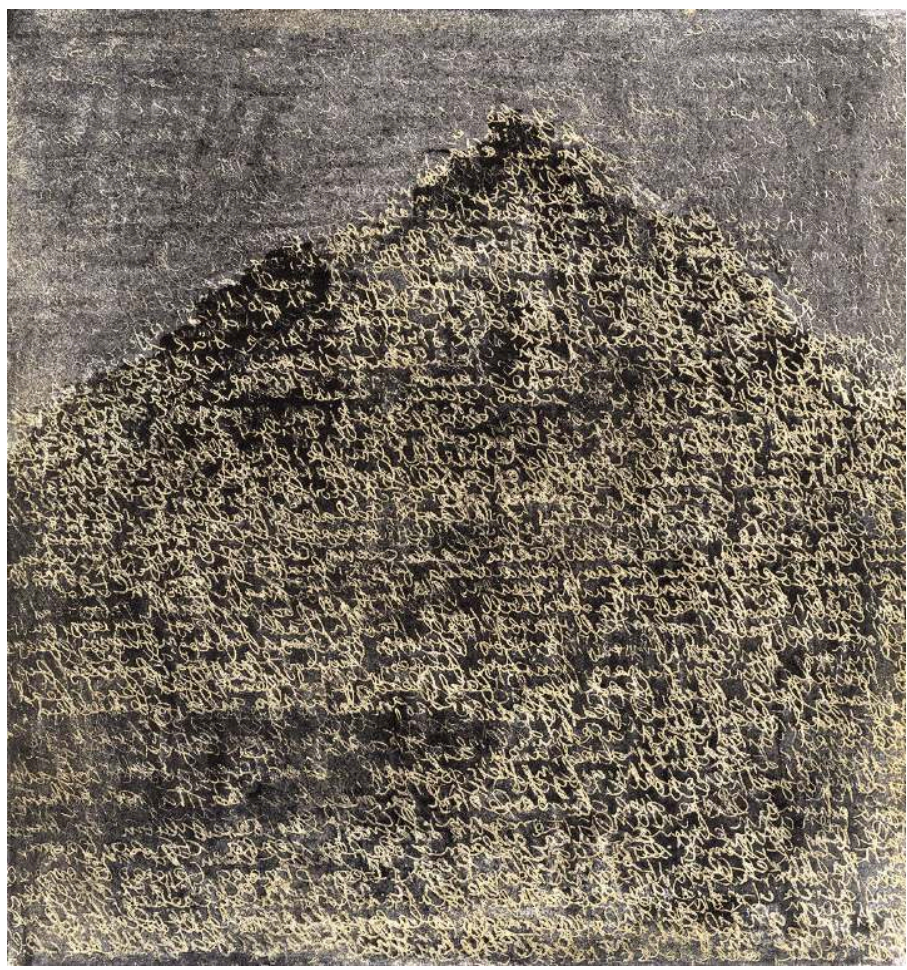

Fig. 10 - Ian Joyce, An T-Earigal Dubh'Donegal, etching, 2000.

Photo credit: Ian Joyce.

from the "ages of anxiety". If it is merely a direction, a pointing finger stump attached to a tree bowl, it is also a cluster of buildings, a modern clachan in a landscape where things go on being printed, painted, sculpted outside of wedlock with their new age cousins, their descendants: new media, a UV printing down frame and the world wide web.

Cló literally means stamp, form, type, print, impression, shape or residue. It reflects the life that is lived when we think in Irish, making sense of work as shaping, making shapes, throwing shapes as Cló connects to Claochló (shape shifting, or metamorphosis), deeper and stronger than the idea of "print" in English. Like a foot print or a dip in a hardened cow pat it is three-dimensional, although there is no equivalent word in Irish for three dimensions (or even for two). Cutting turf and licking a stamp are very different experiences in English but Cló covers both and much more besides.

Setting Cló \& The Living Archive in a landscape (the setting of Mín a' Leá) is more to do with the facts and figures of the locality than the beauty of an idealized picture-postcard view. Beauty is not in the eye of the beholder but in the hands that work the land, plunge into the bog, tidy the turf stack, wash the kettle and put the clock away at night. Turbary rights and commonage, the vicissitudes of working 
the stony soil makes for an economy of an entirely other form of work, with work exchange and labour sharing, a matter of communal survival (meitheal). Cló, as a living archive, turns over the sod of images.

Finding no-one about and nothing in sight, the artist, neither victim nor perpetrator, eschews the world weariness of a trans-European re-visitation of schadenfreude and in the light of the darkness of night, in the absence of moonlight or moonshine, on the darkest of all nights, goes skinny dipping under the stars in the Duibheagán.

Ian JoYce

Multi-media artist and printmaker

Mathew Staunton

École nationale supérieure des arts décoratifs - ENSAD 